\title{
Assessment of Nurses' Knowledge and Attitude toward Infection Standards Precautions in Primary Health Care Settings
}

Sahar Mohamed Soliman*

\begin{abstract}
Background: Standards precautions are designed to protect staff from risks resulting from exposure to blood and body fluids and to protect patients from potential cross infection. Knowledge of clinical infection control practices is continually growing and changing. Objectives: the present study was conducted to assess nurses' Knowledge about Infection control standards precautions in primary health care settings. Methods: This study was cross sectional study that was conducted in six primary health care settings (PHC) in Manzala District affiliated to the Ministry of Health and Population. PHC settings were selected by stratified random sample method. Seventy nine nurses were included in the study. Data were collected by using open ended questions sheet, which was self-administered. Results: The nurses showed a poor level of knowledge regarding most categories of standard precautions. Conclusion and Recommendations: Mandatory regular base educational program must be planned to overcome the weak level of knowledge and improve and update the nursing performance regarding standard precautions.
\end{abstract}

Key wards: Standard precautions; Knowledge; Attitude; Nurses

\section{INTRODUCTION}

Infection control practice is a corner stone of modern health care ${ }^{(1)}$. Universal precautions are simple infection prevention control measures that reduce the risk of transmission of blood borne pathogens through exposure to blood and body fluids among patients and health care workers (HCWs). Compliance with these universal precautions has significantly reduced the risk of exposure to blood and body fluids that workers will contract in the course of their work"(2). The term "standard precautions" is replacing "universal precautions," as it expands the coverage of universal precautions by recognizing that any body fluid may contain contagious and harmful microorganisms ${ }^{(3)}$. Standards precautions are designed to protect staff from risks that resulting from exposure to blood and body fluids and to protect patients from potential cross infection.

The level of knowledge and quality of training may influence practice of standard precautions. $^{(4)}$ Knowledge of clinical infection control practices is continually growing and changing. Nurses play a crucial role in

${ }^{\star}$ Community Health Nursing, Faculty of Nursing Mansoura University 
preventing and controlling infectious diseases through application of standard precautions and maintenance of the health care environment. All nurses, in all roles and settings, can demonstrate leadership in infection prevention and control by using their knowledge, skills and judgment to initiate appropriate and immediate infection control procedures.(5) Lack of knowledge regarding standard precautions was found among health care workers in general and specifically among nurses. Lack of knowledge among $48 \%$ of Nigerians health care workers, lead to poor adherence to standard precautions. ${ }^{(6)}$

In Egypt, it was reported that nurses' knowledge regarding universal precautions was below the average score. ${ }^{(7)}$ Therefore, the present study was conducted to assess nurses' Knowledge about infection control precautions.

MATERIAL AND METHODS

Study design:

Cross-sectional study was used to assess the knowledge of nurses about infection control standard precautions.
Setting:

The study was conducted in Maternal and Child Health $(\mathrm{MCH})$ centers affiliated to Ministry of Health and Population at Manzala District, Dakahlia Governorate. The studied settings were selected by random sample method to represent $6 \mathrm{MCH}$ centers out of ${ }^{18}$ centers, namely El-Hadary Center, Al-Kamel Health Center, El-Frosat Health Unit, ElAzizha Health Center, the Second Child Health Center, and El-Sabteha Health Unit.

\section{Subject:}

All nurses currently working during the study were included in the sample. Total number of nurses was 107 nurse, 97 were currently working during the study, only 79 complete the questionnaire. The involved nurses were 68 nurses who have diploma degree and 11 technical nurses with associate degree.

Tool:

Assessment tool consisted of four parts:

The first part included personal and occupational data; such as qualification, years 
of experience, and receiving of training programs.

The second part included nine questions to describe the nurses' behavior regarding infection control measures.

The third part included 22 questions for knowledge with total score of 43 to assess the nurses' knowledge about the infection control standard precautions in $\mathrm{MCH}$ clinics. Components of infection control standard represented by one question ( 5 scores), hand hygiene (2 scores), and personal protective devices (3 scores). Methods of decontamination for instruments and surfaces were presented by 14 questions (14 scores). Handling of waste and linen consisted of 3 questions (7 scores). Knowledge about needle stick and its allied diseases consisted of 2 questions (8 scores).

The level of knowledge was categorized as poor $<50 \%$ (21.4 scores), fair $50 \%-65 \%$ (21- 27.9 scores), and good $>65 \%$ (28 scores). Open-ended questions were used to avoid guessing. The fourth part included 3Likert scale (agree, uncertain, and disagree) to assess nurses' attitude toward infection control measures. The scale included 14 items with total 28 scores, 11 questions measure the positive attitude about hand washing, protective measures, handling needles and its allied effect, and waste disposal, three of them had negative attitude. The level of attitude was categorized as poor $<50 \%$ (14 scores), fair $50 \%-65 \%$ (14- 18.2 scores), and good $>65 \%$ (18.2 scores). Open-ended questions were used to avoid guessing.

\section{Methods:}

1-Administrative process:

a- Official approval was obtained from the Ministry of Health and Population

2-Development of the study tool:

a- The researcher developed the tool after reviewing of recent literatures.

c- Validity of tool was tested by experts in that field

b- A pilot study was carried out on 10 nurses were chosen randomly from $\mathrm{MCH}$ centers to ensure the clarity of the knowledge test. 
3- Data collection: Data were collected by usingduring the years of work ranged from 1-10 the self-administered structured questionnairetimes. The nurses' knowledge about infection sheet, during actual visit to $\mathrm{MCH}$.

control measures was presented in Table (2).

Statistical analysis:

SPSS package (version 0.9) was used for the statistical analysis of the obtained data; Independent t- test was used to estimate the significant differences between different variables.

\section{RESULTS}

Table (1) shows the distribution of nurses according to their occupational data, $68(86.1 \%)$ of nurses have diploma degree and 11 (13.9\%) have technical degree. Most of nurses 40 (50.6\%) have less than 5 years experience while the $14(17.7 \%)$ have more than 10 years of experiences. $51(64.6 \%)$ of nurses received training about infection control. Only $5(6.1 \%)$ of them received three doses of hepatitis B vaccine. Regarding the occurrence of needle stick injures during this year, $10(12.7 \%)$ of nurses complained from needle stick injury that ranged from 1-8 times while their complained from needle stick injury
Results revealed that $76(96.2 \%)$ and 29 $(36.7 \%)$ of nurses identified hand hygiene and decontamination as components of infection control measures, respectively; with mean score of $1.9 \pm 1.2$. Times of hand hygiene was correctly identified by most of nurses, 69 (87.3\%), while 7 (9.9\%) only describe correctly the proper technique of hand hygiene. Regarding personal protective measures, gloving is the most personal protective devices that nurses are knowledgeable about. 72 (97.1\%) Nurses gained mean score of $2.8 \pm$ 0.7 for hand hygiene and personal protective measures.

Three quadrants 60 (75.6\%) of nurses mentioned correctly betadine as a type of disinfectant. About one-third of nurses, 25 (31.6\%), was able to define sterilization, while $57(72.2 \%)$ and $14(17.7 \%)$ of them mentioned autoclave and hot oven as methods of sterilization respectively. But no one have knowledge about cleaning surfaces. 
Nurses have a good knowledge about waste segregation namely, sharps 70 (88.6\%) and infectious items 69 (86.1\%). Concerning type of containers only $25(31.6 \%)$ of nurses were knowledgeable about safety box as a containers for sharps, and 58 (70.8\%) of nurses mentioned that red plastic bags were used as container for infectious items. On the other hand, only $14 \quad(17.7 \%)$ described correctly the collection of wet linen with blood and secretions. Nurses gained mean score of 2.5 \pm 0.9 for handling waste and linen.

Table (3) shows knowledge of nurses about needle stick, as regards to nurses' action after needle stick $5(6.3 \%)$ of nurses have knowledge about removing the glove immediately after needle stick, $3(3.8 \%)$ of them mentioned washing hands, only one mentioned to disinfect the injury site, and no one have knowledge about incidence report. On the other hand, 71 (89.9\%) of nurses have a correct knowledge about diseases transmitted by needle stick namely; hepatitis $\mathrm{B}, \mathrm{C}$, and HIV. It is apparent from table (4) that the majority of nurses $65(82.3 \%)$ had poor knowledge about infection control and 14 $(17.7 \%)$ of them had fair knowledge. The over all mean of nurses score is $15.7 \pm 4.1$

Table (5) revealed that the knowledge of nurses regarding infection control showed significant difference $(<0.05)$ between diploma and technical nurses with mean of $15.1 \pm 3.9$ and $19.5 \pm 3.4$, respectively. Nevertheless, there is no significant difference between nurses who received training program about infection control and those who did not receive training program.

Table (6) illustrates nurses attitude toward infection control measures as regards to protective measures and hand hygiene's. The majority of nurses have positive attitude toward hand washing 75 (94.9\%) and 74 $(93.7 \%)$ of nurses mentioned that hand hygiene be replaced by gloving. Using protective measures can prevent transmission of infection to health care worker and from infected patient to other patient 72 (91.1\%) and 70 (86\%), respectively. Nurses score is $10.9 \pm 1.8$ regarding to protective measures and hand hygiene. As regards to handling of needles and its allied effects 7 (8.9\%) of 
nurses have negative attitude toward covering needle after using. Most of nurses 77 (97.5\%) agreed that diseases transmitted by needle stick are dangerous and all of them have positive attitude that these diseases can be prevented. Their score related to handling needle and its allied effect is $9.7 \pm 0.7$. Concerning waste handling, the majority of nurses $68(86.1 \%)$ have positive attitude toward waste segregation. Nurses gain $3.7 \pm 0.7$ scores about this item.

Table (6) elaborates that the majority of nurses showed a good attitude toward infection control measures. The over all mean is $24.5 \pm 2.3$.

\section{DISCUSSION:}

Standard precautions are effective strategies to prevent and control nosocomial infections. Nurses must be knowledgeable about the principles of standard precautions ${ }^{(3)}$. Despite of this, many studies attributed the poorness of adherence to universal precautions, to the lack of knowledge. ${ }^{(6-9)}$ These researches support the present study, which revealed that most of nurses in general showed poor knowledge level regarding standard precautions.

Transmission of microorganisms from the hands of healthcare workers is the main source of cross-infection in health care settings and can be prevented by hand washing. Akyol (2007) revealed that nurses have a poor level of knowledge concerning quality of hand washing(8). This study is in agreement with the present study which found a minor number of nurses described the appropriate technique of hand washing, although they have a good knowledge and attitude about appropriate times for hand washing.

A minor percentage of nurses mentioned personal protective equipment as one of the standard precaution components, although they showed a good level of knowledge regarding identification of these items. This is in agreement with a Brazilian study which revealed that $75.6 \%$ of nurses understand standard precautions as protective measures. ${ }^{(10)}$ In addition to the reported results of Ganczak and Szych 2007, that 
indicated low knowledge regarding personal protective equipment among nurses in Poland(11).

Regarding to decontamination process; the majority of nurses lacked in knowledge about the disinfection and sterilization process. These results are in agreement with Grillo et al., (2004), who reported that a large number of nurses do not know the correct procedures of disinfection and sterilization procedures.(12). Also, Beder and Michel (2004) found that only $12 \%$ of nurses have satisfactory knowledge level about sterilization process ${ }^{(13)}$.

As regards to needle stick injury, studies showed that $40 \%$ out of 110 nurses reported multiple needle stick injuries but staff frequently don't report the injury despite their awareness of the risk of blood borne pathogenesis ${ }^{(14,15)}$. These findings supported the present results as nurses showed a poor knowledge about the action taken when needle stick occurred, although 12.6\% exposed to multiple needle stick injury. In addition, Bennett and Mansell (2004) found that the majority of community nurses reported compliance with standard precautions, although a small number of nurses stated that they re-sheathed needles and inadequately wore gloves ${ }^{(16)}$. In addition, most of the studied nurses have a good knowledge and attitude toward the occupational hazards that they are exposed such as hepatitis B, C, and HIV. This is in agreement with a study in Gaza done by Massrouje 2001 who found that nurses knew that viral hepatitis and HIV infection could be transmitted as a result of the improper management of medical waste..$^{(17)}$

Regarding to infection control training the present result revealed insignificant difference between nurses who received training program about infection control and those who did not receive training program. The Royal College of Nursing believed that all health care staff should receive mandatory infection control training as part of their education and on an ongoing annual basis. It is important that knowledge and skills be continually updated. The training should cover all the general principles of infection 
prevention and control to minimize the spread of infection(18). El-Shafie et al.,(7) 1995, and Beder and Michel $(2004)^{(13)}$, reported that nurses need training programs in a regularbasis.

\section{Conclusion and Recommendations}

It was conclude that most of nurses who involved in the study showed poor knowledge level regarding standard precautions. The study recommended that:
1. An in-service- training program should be designed and applied on regular basis

2. Follow up; monitoring, and evaluation of the nurses' clinical infection control practice should be done

3. Nurses must apply measures to prevent and control transmission of infection. 
Table 1: Distribution of nurses according to their occupational data

\begin{tabular}{|c|c|c|}
\hline Items & $\begin{array}{c}\text { Number } \\
79\end{array}$ & $\%$ \\
\hline \multicolumn{3}{|l|}{ Educational level } \\
\hline Diploma & 68 & 86.1 \\
\hline Technical & 11 & 13.9 \\
\hline \multicolumn{3}{|l|}{ Experience years } \\
\hline$\leq 5$ & 40 & 50.6 \\
\hline-10 & 25 & 31.6 \\
\hline$>10$ & 14 & 17.7 \\
\hline Mean \pm S.D & \multicolumn{2}{|c|}{$7.8 \pm 6.1$} \\
\hline \multicolumn{3}{|l|}{ Training of infection control } \\
\hline Received training & 51 & 64.6 \\
\hline \multicolumn{3}{|l|}{ Receiving vaccine of hepatitis $B$} \\
\hline 3doses & 5 & 6.1 \\
\hline$<3$ doses & 9 & 11.3 \\
\hline \multicolumn{3}{|c|}{ Occurrence of needle stick this year } \\
\hline 1-3 time & 5 & 6.3 \\
\hline 4-8 time & 5 & 6.3 \\
\hline \multicolumn{3}{|c|}{ Occurrence of needle stick during the years of work } \\
\hline $1-5$ time & 6 & 7.6 \\
\hline $6-10$ time & 4 & 5 \\
\hline
\end{tabular}


Table 2: Distribution of nurses according to their knowledge about infection control measures

\begin{tabular}{|c|c|c|c|}
\hline Items & $\begin{array}{c}\text { Number } \\
79\end{array}$ & $\%$ & Scores \\
\hline $\begin{array}{l}\text { Components of infection control measures } \\
\text { Hand hygiene } \\
\text { Decontamination } \\
\text { Personal protective measures } \\
\text { Waste disposal } \\
\text { Aseptic techniques }\end{array}$ & $\begin{array}{l}76 \\
29 \\
10 \\
6 \\
1\end{array}$ & $\begin{array}{l}96.2 \\
36.7 \\
12.7 \\
7.6 \\
1.3\end{array}$ & $1.9 \pm 1.2$ \\
\hline $\begin{array}{l}\text { Hand hygiene } \\
\text { Times } \\
\text { Techniques }\end{array}$ & $\begin{array}{c}69 \\
7\end{array}$ & $\begin{array}{c}87.3 \\
8.9\end{array}$ & \multirow[b]{2}{*}{$2.8 \pm 0.7$} \\
\hline $\begin{array}{l}\text { Personal protective measures } \\
\text { Glove } \\
\text { Apron } \\
\text { Mask }\end{array}$ & $\begin{array}{c}72 \\
12 \\
1\end{array}$ & $\begin{array}{c}97.1 \\
15.2 \\
1.3\end{array}$ & \\
\hline $\begin{array}{l}\text { Decontamination } \\
\text { Definition of disinfection } \\
\text { Types of disinfectants (Betadine) } \\
\text { Definition of sterilization } \\
\text { Types of sterilization } \\
\text { Autoclave } \\
\text { Hot oven } \\
\text { Time \& Temp of hot oven } \\
\end{array}$ & $\begin{array}{c}7 \\
60 \\
25 \\
\\
57 \\
1 \\
14\end{array}$ & $\begin{array}{c}8.9 \\
75.9 \\
31.6 \\
72.2 \\
1.3 \\
17.7 \\
\end{array}$ & $4.5 \pm 2.0$ \\
\hline $\begin{array}{l}\text { Waste } \\
\text { Segregation }\end{array}$ & & & \multirow{9}{*}{$2.5 \pm 0.9$} \\
\hline Sharps & 70 & 88.6 & \\
\hline Infectious & 69 & 86.1 & \\
\hline Pathological waste & 8 & 10.1 & \\
\hline Type of containers & & & \\
\hline Safety box for sharps & 25 & 31.6 & \\
\hline Red plastic bags for infectious & 58 & 70.8 & \\
\hline Linen & & & \\
\hline Collection of wet linen with blood & 14 & 17.7 & \\
\hline
\end{tabular}

Table 3: Distribution of nurses according to their knowledge about needle stick

\begin{tabular}{|c|c|c|c|}
\hline Items & $\begin{array}{c}\text { Number } \\
79\end{array}$ & $\%$ & Scores \\
\hline \multicolumn{4}{|l|}{ Action after needle stick } \\
\hline Remove the glove & 5 & 6.3 & \\
\hline Hand hygiene & 3 & 3.8 & $2.6 \pm 0.8$ \\
\hline Disinfect the site of injury & 1 & 1.3 & \\
\hline $\begin{array}{l}\text { Common disease transmitted by needle stick } \\
\text { Hepatitis } B, C \text { viruses, and HIV }\end{array}$ & 71 & 89.9 & $0.9 \pm 0.3$ \\
\hline
\end{tabular}


Table 4: Level of nurses' knowledge regarding infection control

\begin{tabular}{|c|c|c|}
\hline Item & $\begin{array}{c}\text { Number } \\
79\end{array}$ & $\%$ \\
\hline Poor & 65 & 82.3 \\
\hline Meant S.D & \multicolumn{2}{|c|}{$14.4 \pm 3.2$} \\
\hline Fair & 14 & 17.7 \\
\hline Mean士 S.D & \multicolumn{2}{|c|}{$21.7 \pm 1.6$} \\
\hline Overall mean \pm S.D & & \\
\hline
\end{tabular}

Table 5: Distribution of nurses about their attitude toward infection control measures

\begin{tabular}{|c|c|c|c|}
\hline Items & $\begin{array}{l}\text { Number } \\
79\end{array}$ & $\%$ & Scores \\
\hline \multicolumn{4}{|l|}{ Personal protective measures and hand hygiene } \\
\hline Washing hands is necessary & 75 & 94.9 & \multirow{6}{*}{$10.9 \pm 1.8$} \\
\hline Wearing gloves when dealing with patient is necessary & 74 & 93.7 & \\
\hline Wearing gloves instated of hand washing & 9 & 11.4 & \\
\hline $\begin{array}{l}\text { Using personal protective measures can prevent transmission of } \\
\text { infection to health care workers }\end{array}$ & 72 & 91.1 & \\
\hline $\begin{array}{l}\text { Using personal protective measures can prevent infection } \\
\text { transmission from infected patient to others }\end{array}$ & 70 & 86.0 & \\
\hline $\begin{array}{l}\text { Changing personal protective measures between clients is } \\
\text { necessary }\end{array}$ & 66 & 83.5 & \\
\hline \multicolumn{4}{|l|}{ Handling of needles and its allied health effects } \\
\hline Needle should be bent after using & 1 & 1.3 & \multirow{6}{*}{$9.7 \pm 0.7$} \\
\hline Covering the needle after using is necessary & 7 & 8.9 & \\
\hline Diseases transmitted by needle stick are dangerous & 77 & 97.5 & \\
\hline Nurses complain from these diseases can effect her life & 78 & 98.1 & \\
\hline Infection can be transmitted from health care workers to patient & 32 & 40.5 & \\
\hline Blood borne infection can be prevented & 79 & 100 & \\
\hline \multicolumn{4}{|l|}{ Waste disposal } \\
\hline Safety box is safe & 77 & 97.5 & \multirow[t]{2}{*}{$3.7 \pm 0.7$} \\
\hline Segregate waste is necessary & 68 & 86.1 & \\
\hline
\end{tabular}


Table 6: Level of attitude of nurses regarding infection control measures

\begin{tabular}{|c|c|c|}
\hline Item & $\begin{array}{c}\text { Number } \\
79\end{array}$ & $\%$ \\
\hline $\begin{array}{l}\text { Fair } \\
\text { Mean } \pm \text { S.D }\end{array}$ & 2 & $17 \pm 1.4$ \\
\hline $\begin{array}{l}\text { Good } \\
\text { Mean } \pm \text { S.D }\end{array}$ & 77 & $24.5 \pm 1.9$ \\
\hline
\end{tabular}

Table 7: Difference of nurses' knowledge regarding level of education and receiving training program in infection control

\begin{tabular}{lccc}
\hline Item & Mean \pm S.D & t- & P \\
\hline Education & $15.1 \pm 3.9$ & & \\
$\begin{array}{l}\text { Diploma } \\
\text { Technical }\end{array}$ & $19.5 \pm 3.4$ & 3.6 & 0.001 \\
\hline Training & $15.8 \pm 4.2$ & & \\
Yes & $15.4 \pm 4.0$ & 0.44 & 0.65 \\
No & & \\
\hline
\end{tabular}

\section{REFERENCES}

1. Watkins RE, Wynaden D, Hart L, Lands borough I, Mcgowan S, Speed G, et al.. Perception of infection control practices among health professionals. Contemp Nurse. 2006; 22(1): 109-19.

2. Chan R, Molassiotis A, Chan E, et al. Nurse knowledge of and compliance with universal precaution in an acute care hospital. Int J Nurs Stud. 2002; 39:157-63.

3. Sridhar MR, Boopathi S, Lodha R, et al. Standard precautions and post exposure prophylaxis for preventing infection. Indian J Paediatr. 2004; 71: 617-26.
4. Ofili AN, Asuzu MC, Okojie $\mathrm{OH}$. Knowledge and practice of universal precaution amongst nurses in Central Hospital, Benin City, Edo State, Nigeria. Niger Postgrad Med J. 2003; 10:26-31.

5. Practice Standard: Infection Prevention and Control. canada: College of Nurses of Ontario; 2005..

6. Aisien $\mathrm{AO}$, Shobowale MO. Health care workers' knowledge on HIV and AIDS: universal precautions and attitude towards PLWHA in Benin-City, Nigeria. Niger J Clin Pract. 2005;8(2):74-82.

7. El-Shafie IF, Mokabel FM, Helmy FE. The relationship between the knowledge of nursing staff and their compliance to universal precautions for prevention of hepatitis B viral infection. J Egypt Public Health Assoc. 1995; 70(5-6):523-40. 
8. Akyol AD. Hand hygiene among nurses in Turkey: opinions and practices. J Clin Nurs. 2007;16(3):431-7

9. Gauld D. Nurses hand decontamination practice: results of a local study. Journal of Hospital Infection. 1994;28 (suppl.B): 15-6.

10. Melo DDS, Souza ACS, Tipple AFV, Das Neves ZCP, Pereira MS. Nurse's understanding of standard precautions at a public hospital in Goia, nia-go, Brazil. Revista Latino-Americana de Enfermagem. 2006;14 (5): 720-7.

11. Ganczak M, Szych Z. Surgical nurses and compliance with personal protective equipment. Journal of Hospital Infection. 2007;66(4): 346-51.

12. Grillo OC, Alfino D, Anzalone C, Cannavo G, Ventura Spagnolo E. Knowledge of disinfection practices and behaviour of the nursing staff at a hospital. Ann Ig. 2004;16(1-2):341-9.

13. Beder AN, Michel WH. Impact of universal infection control intervention program for nurses. Alexandria
Scientific Nursing Journal. 2004; 3(1):13-26.

14. Lee JM, Botteman MF, Nicklasson L, Cobden D, Pashos CL. Needle stick injury in acute care nurses caring for patients with diabetes mellitus: A retrospective study. Current Medical Research and Opinion. 2005;21, (5): 741-7

15. Tabak N, Shiaabana AM, Shasha S. The health beliefs of hospital staff and the reporting of needle stick injury. J Clin Nurse. 2006;15(10): 1228-93.

16. Bennett G, Mansell I. Universal precautions: a survey of community nurses' experience and practice. J Clin Nurs. 2004;13 (8): 1017-9.

17. Massrouje HTN. Medical waste and health workers in Gaza governorates. Eastern Mediterranean Health Journal. 2001; 7 (6): 1017-24

18. Royal College of Nursing. Good practice in infection prevention and control Guidance for nursing staff. UK: 2005 